\title{
4-(N-アリル- $\mathbf{N}_{\text {-トシルアミノ)ナフタル }}$ 酸-N-メチルイミドの転位反応
}

\section{稲田正作*.有川晶*.岡崎光雄*}

\author{
Rearrangement of 4-(N-Allyl-N-tosylamino)naphthal-N-methylimide
}

Seisaku INADA*, Akira ARIKAWA* and Mitsuo OKAzAKI*

\begin{abstract}
It was found that 4-(N-allyl-N-tosylamino)naphthal-N-methylimide (2) rearranged to 3-allyl-4-tosylamino derivative (3) by a first-order mechanism. When heated at $230^{\circ} \mathrm{C}$ for $12 / 3$ hours under a reduced pressure, (2) was converted into (3) in $74.5 \%$ yield, but further heating brought the decomposition of the reaction mixture. The decomposition was attributed to the presence of atmospheric oxygen. The rate constant of the rearrangement is $7.6 \times 10^{-5} \mathrm{sec}^{-1}\left(213.1^{\circ} \mathrm{C}\right)$ by no use of solvent and $6.1 \times 10^{-5} \sec ^{-1}\left(213.0^{\circ} \mathrm{C}\right)$ in $\mathrm{N}, \mathrm{N}$-diethylaniline.
\end{abstract}

The structure of (3) was confirmed by covnerting it to 3-propenyl-4-tosylamino derivative (4) (which was also obtained from the known 3-allyl- (5) and 3-propenyl-4-methoxy derivative (6) respectively) and further, to the cyclization product (7) by bromine.

The sulfuric acid-hydrolysis of (2) and (3) was attempted.

\section{概 要}

4-(N-アリル-N-トシルアミノ) ナフタル酸-N-メチ ルイミド（2）のアリル基が熱処理によって 0 -位に転位 し，3-アリル-4-N-トシルアミノナフタル酸-N-メチル イミド (3) となることを見いだした。たとえば，(2) を 減圧下 (2 $3 \mathrm{mmHg})$ 飞 $230^{\circ} \mathrm{C}$ で $12 / 3$ 時閒加熱すれ ば，74.5\% の収率で (3) を得ることができる。しかし， この条件下にさらに加熱をつつけると, ある時点で反応 混合物は急激に分解する。この分解が共存する酸素の影 響によるものであることを定性的に示した。また，この

†本報を「アミドークライゼン転位反忘に関する研究」 第 1 報とする。

* 東京工業大学工学部合成化学科

* Faculty of Engineering, Tokyo Institute of Technology
転位反応が笤溶媒および $\mathrm{N}, \mathrm{N}-$-ジェチルアニリン溶媒中 で 1 次反応に属し，その速度 定数はそれぞれ $7.6 \times 10^{-5}$ $\sec ^{-1}\left(213.1^{\circ} \mathrm{C}\right), 6.1 \times 10^{-5} \sec ^{-1}\left(213.0^{\circ} \mathrm{C}\right)$ であること を認めた。

転位生成物の構造が (3) であることは，(3) から，京 た，3ーアリルー（5）および 3-プロペニルー4-メトキシ体 （6）からそれぞれ 3-プロペニルー4ートシルアミノ体 (4) を誘導することにより，またさらに，(3) から臭素によ り閉環化合物 (7) が生成したことからも確認された。

(2) および (3) の硫酸による加水分解を試みた。(2) からは 64\% の収率で目的とする 4-アリルアミノ体 (9) を得たのに齐して，(3) から相当子る 3-アリルー4-ア ミノ体 (14) を単離することができず, 別の経路によっ て合成した。

\section{I. 䋨 容}

アリルフェニルエーテルから 0 アリリルフェノールヘ 
の [3,3]シグマトロピ一転位はクライゼン転位反応と して知られ，現在までにかなり詳細な研究が行なわれて いる。一方，その $\mathrm{N}$-analog のアミノクライゼン転位 反応については，F.B. Dains ら ${ }^{1 a)}$ および F.L. Carnahan $ら^{1 \mathrm{~b})}$ が N-アリルをたは $\mathrm{N}$-アリル-N-トシルア ニリンの熱反応を検討し，いずれも分解生成物のみを得 たと報告している。その後しばらくの間はアリルアリー ルアミンについて 2,3 の酸接触転位が試みられたのみ で，いわゆるアミノクライゼン転位についての報告はま ったくない。しかし，1961年 S. Marcinkiewicz ら ${ }^{2)}$ クライゼン転位に関する一連の速度論的研究の結果から アミノクライゼン転位の可能性について論及し， N-ア リルー1-ナフチルアミンから, $280^{\circ} \mathrm{C}$ で 3 時間加熱する ことによって 90\% 収率で転位体 2-アリル-1-ナフチル アミンを得ることに成功している。なお，このほかエナ ミンからのアリル転位 ${ }^{3}$, 複素環窒素からのアリル転位 ${ }^{4}$ について，現在では興味ある報告がある。

著者らはさきに 4-アリルオキシナフタル酸-N-メチ ルイミドのクライゼン䎐位反态によってナフタル酸イミ ドの各種誘導体を合成し，それらのケイ光性を検 討し $た^{5)}$ 。この化合物の転位反応飞興味をもったので，前記 のように従来ほとんぞ未開拓の分野であるアミノクライ ゼン転位反応にこれを拡張すべく本研究に着手した。

出発原粕となるアリルアリールアミンについては, 芳 香族アミンの N-アリル化が必ずしも容易ではない。た とえば, Marcinkiewiczらは1ーナフチルアミンを常法に したがって臭化アリルと炭酸カリウム存在下にアセトン 中で煮沸還流してアリル化しているが，精製が困難で目 的物をわずかに $11.2 \%$ の収率で得ているに過ざない。 これに対して N-トシルアリールアミン類はアリル化が 容易であり，かつトシル基の存在が転位を有利にするこ とが予想されたので, 本研究においては転位原料として N-アリルーN-トシル体（2）を用いることにした。

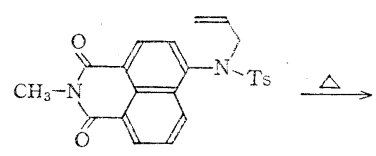

(2)

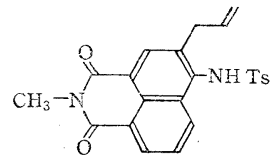

(3)

\section{II. 実験結果と考察}

1. 転位反応 4-(N-アリル-N-トシルアミノ) 体 (2) から 3-アリル-4-N-トシルアミノ体 (3)への 213.1 $\pm 0.2^{\circ} \mathrm{C}$ における転位反応の結果を表1a〜cに示した。 表 1a は常圧下, 表 1b は 12 13 mmHg 減圧下, 表 1c 2 2 3mHg 減圧に挨いて, いずれも (2) $2.00 \mathrm{~g}$
を無溶媒で加熱転位させた結果である。

表 1a 4-(N-アリル-N-トシルアミノ) ナフタル酸Nーメチルイミド（2）の転位 (常圧)

\begin{tabular}{|c|c|c|c|c|c|c|}
\hline 時閒(分) & & \multirow{2}{*}{$\begin{array}{l}90 \\
0.70\end{array}$} & \multirow{3}{*}{$\begin{array}{l}120 \\
0.86 \\
43.0\end{array}$} & \multirow{3}{*}{$\begin{array}{l}150 \\
0.97 \\
48.5\end{array}$} & \multirow{3}{*}{$\begin{array}{l}180 \\
0.95 \\
47.5\end{array}$} & \multirow{3}{*}{$\begin{array}{l}210 \\
0.03 \\
1.5\end{array}$} \\
\hline \multirow{2}{*}{ (3) } & \multirow{2}{*}{$\begin{array}{c}60 \\
0.49 \\
24.5\end{array}$} & & & & & \\
\hline & & \multirow{3}{*}{$\begin{array}{l}1.30 \\
65.0\end{array}$} & & & & \\
\hline 旬収原料 g & \multirow{2}{*}{$\begin{array}{l}1.47 \\
73.5\end{array}$} & & \multirow{2}{*}{$\begin{array}{l}1.14 \\
57.0\end{array}$} & \multirow{2}{*}{$\begin{array}{l}1.02 \\
51.0\end{array}$} & \multirow{2}{*}{$\begin{array}{l}1.04 \\
52.0\end{array}$} & \multirow{2}{*}{-} \\
\hline (2) $\%$ & & & & & & \\
\hline
\end{tabular}

表1b (12 13 $\mathrm{mmHg}$ 減圧下)

\begin{tabular}{rr|l|l|l|l|l|l}
\hline 時間(分) & 60 & 120 & 180 & 240 & 270 & 300 \\
\hline (3) & $\mathrm{g}$ & 0.48 & 0.87 & 1.14 & 1.26 & 1.09 & 0.02 \\
& $\%$ & 24.0 & 43.5 & 57.0 & 63.0 & 54.5 & 1.0 \\
\hline 回収原料 $\mathrm{g}$ & 1.51 & 1.13 & 0.81 & 0.73 & 0.83 & - \\
\multicolumn{2}{l|}{ (2) $\%$} & 75.5 & 56.5 & 40.5 & 36.5 & 41.5 & - \\
\hline
\end{tabular}

琵 1c $(2 \sim 3 \mathrm{mmHg}$ 隇压下 $)$

\begin{tabular}{rr|l|l|l|l|l|l}
\multicolumn{2}{c|}{ 時間(分) } & 90 & 150 & 180 & 240 & 300 & 315 \\
\hline (3) & $\mathrm{g}$ & 0.68 & 1.01 & 1.13 & 1.30 & 1.27 & 1.03 \\
& $\%$ & 34.0 & 50.5 & 56.5 & 65.0 & 63.5 & 51.5 \\
\hline \multicolumn{2}{l|}{ 回收原料 $\mathrm{g}$} & 1.30 & 0.98 & 0.82 & 0.66 & 0.71 & 0.84 \\
\multicolumn{2}{l}{ (2) $\%$} & 65.0 & 49.0 & 41.0 & 33.0 & 35.5 & 42.0 \\
\hline
\end{tabular}

表中，転位生成物（3）の収率をま之めて 図 1 亿示し た。図 1 に预いていずれの条件でも(3) の収率は同じ 線に沿って上景するが，常圧下では 49\%，12 13 mm $\mathrm{Hg}$ 減圧下では $63 \%, 2 \sim 3 \mathrm{mmHg}$ 減圧下では 65\% をピ

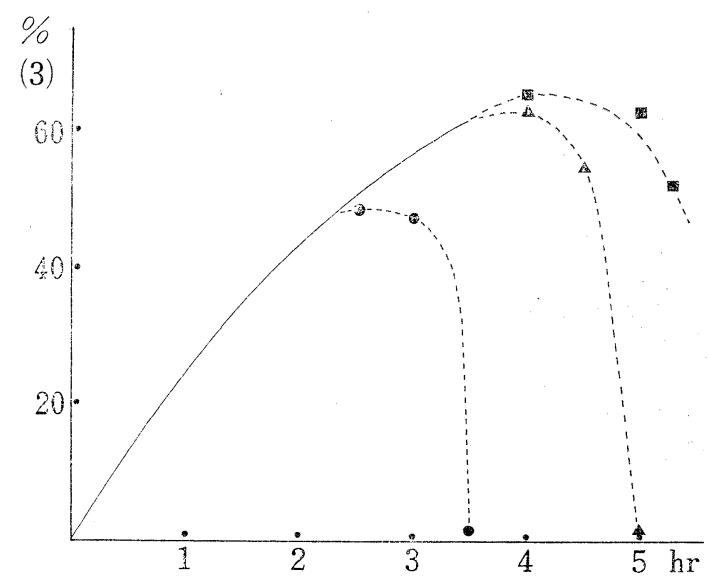

3. 常压 $\triangle 12 \sim 13 \mathrm{mmHg}$ 送 $2 \sim 3 \mathrm{mmHg}$

図 1 (2) の転位

一クとして以後急激に減少している。これはそれぞれ転 位反応のある時点で反応混合物が分解重合するためで, 圧の減少とともに分解の開始が遅れることを示してい 
る。このことから分解は共存する酸素によって誘発され るものと考允られる。最終的には融点 $320^{\circ} \mathrm{C}$ 以上の，ク ロロホルム, 酢酸, ピリジン, DMF などの有機溶媒に 不溶の重合物が多量に生成する。分解の経路としては, 転位生成物 (3) から酸素によってヒドロパーオキシドが 生成し, これが激しい分解を引き起すむのと推定される ので現在その対策を検討中である。なお, クライゼン転 位生成物からヒドロパーオキシドが生成することは 9アリルオキシフェナントレンの転位生成物について確認 されている2)。

な㧍, 図 1 の実線の部分は 1 次反忘としての直線関 係を満足するものであることがわかった（図 2)。速度 定数は $7.6 \times 10^{-5} \mathrm{sec}^{-1}$ である。また, ジェチルアニリ ンを溶媒として転位させた結果を 表 2 に示す。この場 合も初期においては 1 次反応である（図 2 速度定数

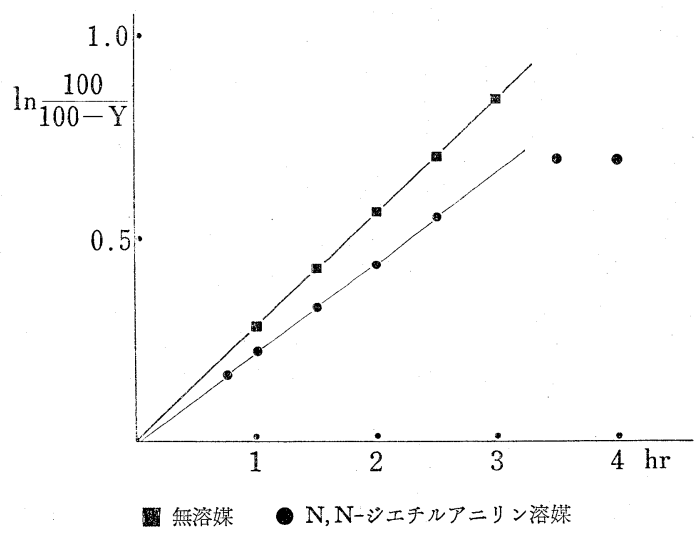

図 21 次反応としての (2) の転位

$\left.6.1 \times 10^{-5} \mathrm{sec}^{-1}\right)$ が， 3 時間以上では直線からはずれ， 分解がおこっていることを示している。なお，この場合 分解生成物の一部として転位原料 (2) および転位生成物 (3) の脱トシル化物（(9) およよび (14)) がそれぞれ pc 上で確認された。

トシル基の導入によって転位速度が早くなることは，

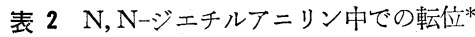

\begin{tabular}{|c|c|c|c|c|c|c|c|}
\hline 時間(分) & 45 & 60 & 90 & 120 & 150 & 210 & 240 \\
\hline \multirow{3}{*}{ (3) } & 0.30 & 0.39 & 0.55 & 0.70 & 0.85 & 1.00 & 1.03 \\
\hline & 15.0 & 19.5 & 27.5 & 35.0 & 42.5 & 50.0 & 51.5 \\
\hline & $\begin{array}{l}218 \\
\sim 9^{\circ} \mathrm{C}\end{array}$ & $\mid \begin{array}{l}220 \\
\sim 2^{\circ} \mathrm{C}\end{array}$ & $\begin{array}{l}219 \sim \\
20.5^{\circ} \mathrm{C}\end{array}$ & $\begin{array}{l}220 \\
\sim 1^{\circ} \mathrm{C}\end{array}$ & $\begin{array}{l}218 \\
\sim 20^{\circ} \mathrm{C}\end{array}$ & $\begin{array}{l}218 \\
\sim 9.5^{\circ} \mathrm{C}\end{array}$ & $\begin{array}{l}217.5 \\
\sim 9.5^{\circ} \mathrm{C}\end{array}$ \\
\hline \multirow{3}{*}{$\begin{array}{c}\text { 回収原料\% } \\
\text { (2) } \mathrm{mp}\end{array}$} & 1.68 & 1.56 & 1.43 & 1.27 & 1.12 & 0.96 & 0.93 \\
\hline & 84.0 & 78.0 & 71.5 & 63.5 & 56.0 & 48.0 & 46.5 \\
\hline & $\begin{array}{r}141.5 \\
\sim 2.5^{\circ} \mathrm{C}\end{array}$ & $\stackrel{140}{\sim 2}{ }^{\circ} \mathrm{C}$ & $\begin{array}{l}142 \sim \\
2.5^{\circ} \mathrm{C}\end{array}$ & $\begin{array}{l}140 \sim \\
1.5^{\circ} \mathrm{C}\end{array}$ & $\begin{array}{r}135.5 \\
\sim 8^{\circ} \mathrm{C}\end{array}$ & $\begin{array}{c}137.5 \\
\sim 9^{\circ} \mathrm{C}\end{array}$ & $\begin{array}{l}131.5 \\
\sim 7.5^{\circ} \mathrm{C}\end{array}$ \\
\hline
\end{tabular}

(2) $2.00 \mathrm{~g}$ を $\mathrm{N}, \mathrm{N}-\ddot{゙}$ エルアニリン $5 \mathrm{ml}$ 中で $213.0 \pm 0.2^{\circ} \mathrm{C}$ に保った。 これらの定数から推測できる。すなわち, N-アリルー1ナフチルアミンの速度定数 (無溶媒) ${ }^{2)}$ は $213.1^{\circ} \mathrm{C}$ にお いて $0.50 \times 10^{-5} \mathrm{sec}^{-1}$ となり，(2)の転位速度の $1 / 15$ にすぎない。本来, クライゼン転位反忘はアリルオキシ 基に対して $p$-位に電子吸引基が存在する場合転位速 度 が若干低下することが観察されており，アミノクライゼ ン転位反応にも適合するものと考えられる。ナフタル酸 イミド類においては 1 位と 8 位に存在するカルボニル基 が電子吸引基として4 位に作用する ${ }^{6)}$ こが考えられ る。にもかかわらず (2)の転位は N-アリル-1-ナフチ ルアミンに比べて早く, その原因はトシル基の存在にあ るといえる。

\section{2. 転位生成物 (3) の構造確認 (3) の構造はその} 元素分析值, IR および NMR の結果と矛盾しないが, なお構造既知の化合物からの誘導によって確認した。は

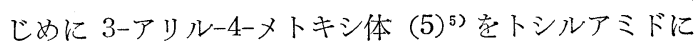
より置換して (3) とする反応を試みた（この反応はスル ホン酸アミドのアニオンによる求核置換反応であり, 類

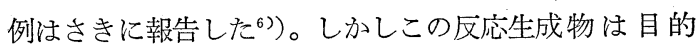
とする（3）よりむかなり融点が高く，その IR は 3275 $\mathrm{cm}^{-1}(\mathrm{NH})$ および $1345,1160 \mathrm{~cm}^{-1}\left(\mathrm{SO}_{2}\right)$ 以外に 965 $\mathrm{cm}^{-1}$ (trans-オンフィンの C-H 面外変角振動) に比較 的強い吸收を示した。また，NMR にも $8.39 \tau$ に $3 \mathbf{H}$ に相当するブロードな二重線が観察されたため, 置換と 同時に二重結合も転位して (4) となったものと推定され た。なお，この場合副生物上して 3-プロペニル-4ーメト

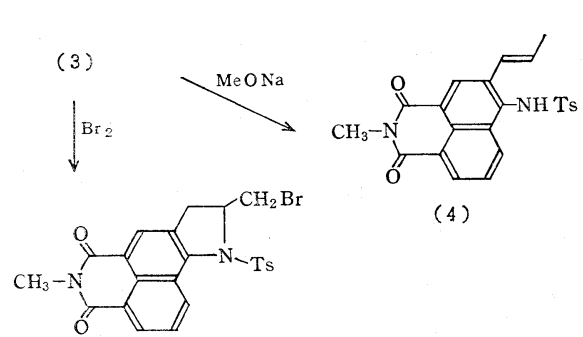

(7)

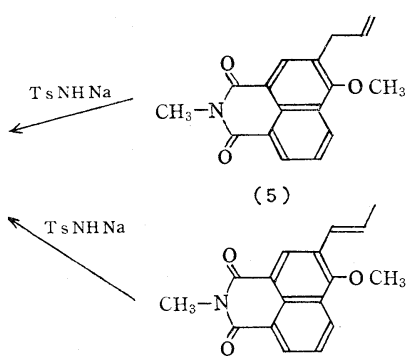

(6) 
キシ体 (6) 5 ) を得たこともこの推定を支持している。こ の二重結合の転位は，DMSO 中スルホン酸アミドアニ オンによるアリル基の $\propto$ 位からのプロトン引き抜きに帰 因するものと考えられる。

そこで (3) を DMSO 中メチラートで処理したところ 予想通り同一生成物 (4) が高収率で得られた。（4）はま た，3ープロペニルー4ーメトキシ体（6）加も同様に合成 された。

なお，クライゼン転位化合物の構造確認によく用いら れる熱あるいは酸接触による閉環反応 ${ }^{5}$ (3) に適用し たところ，いずれも分解重合し，目的物を得ることはで

(3)

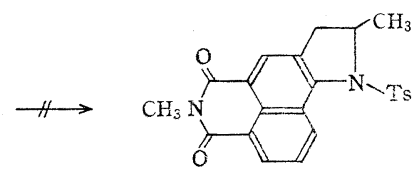

きなかった。酸接触による場合も，(2) の転位あるいは （3）の熱処理の場合と同様にある時点で急激に分解し, 融点 $320^{\circ} \mathrm{C}$ 以上の黄褐色重合物のみを与える。これに対 して臭素による閉環反応では (7) を $80 \%$ 収率で得るこ とができ，アリル基が $o$-位へ䎐位していることを示し ている。

3.（2）および（3）の䟽酸加水分解 （2）を $83 \%$ 硫酸 $(\mathrm{d}: 1.68)$ で加水分解し，目的とする 4-アリルア<smiles>C=CCN(C)c1ccc2c3c(cccc13)C(=O)N(C)C2=O</smiles>

(2)

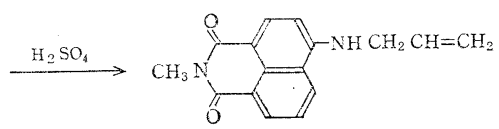

(s)

ミノ体 (9) を64\% 収率で得ることができた。また，こ の場合 $\mathrm{mp} 271 \sim 2^{\circ} \mathrm{C}$ (d) のオレンジ色針状結晶が微量 クロマト分離された。その IR は $\mathrm{NH}$ 領域 $\left(3420,3350,3250 \mathrm{~cm}^{-1}\right)$ の 3 本の吸収拄よび $\mathrm{C}=\mathrm{O}$ 領域の吸 収 $\left(1650,1630 \mathrm{~cm}^{-1}\right)$ が，たとえば 4-アミノナフタル酸-N-メチルイミ゙ ド5の吸収に酷似していることふ ら，アミノ基は第 1 アミンに変化 しているものと推測された。また NMR は $8.82 \tau$ に $3 \mathbf{H}$ 分の, $7.72 \tau$ に $2 \mathbf{H}$ 分の二重線がそれぞれ観察 されることから，アリル基はさら
に 2-置換プロピル基に変化し，加つ $1.95 \tau$ にナフタリ ン核の 2 位のプロトンと考えられる単一線が存在するこ とからその位置は 3 位であると推定した。したがって元 素分析值を考えあわせるとこのものは 3-(2-ヒドロオキ シプロピル)-4-アミノナフタル酸-N-メチルイミド (10) であると推定された。つぎに述べる耘位体 (3) の加水分 解に执いて (10) が得られた事実もこの構造を支持して いる。すなわち，(10）汇図３に示す過程で生成するも のと考えられる。これらはいずれも硫酸接触によって進 行する。なお，(14）の存在は pc上では認められたが単

(2)

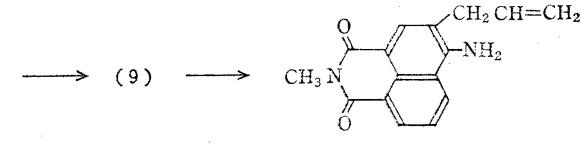

(14)

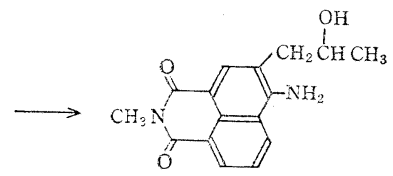

(10)

図 3

離するには至っていない。

謓位生成物 (3) の硫酸加水分解生成物は複雑で, 目的 とする 3-アリルー4-アミノ体 (14) 定得ることはできず, （10）を34\% 収率で単離するにとどまった。そこで図 4 に示した経路によって（14）を合成した。すなわら， アリル基の二重結合を臭素付加こよって保護したのち， 加水分解する経路である。しかし，(3) に直接臭素を反 応させると閉環して (7) が生成するため，あらかじめト シルアミノ基をアセチル化して（11）としたのち，臭素 付加 (12), 加水分解 (13), 脱臭素化反応 (14) を順次 行なった。本法によると・(12) の精製が困難である以外 は比較的容易に（14）を得ることができる。

なお，臭素による閉環化合物 (7) は $83 \%$ 硫酸で容易

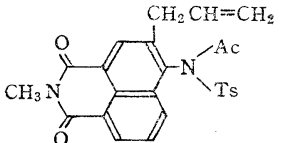

(11)

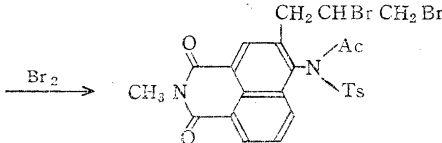

(12)

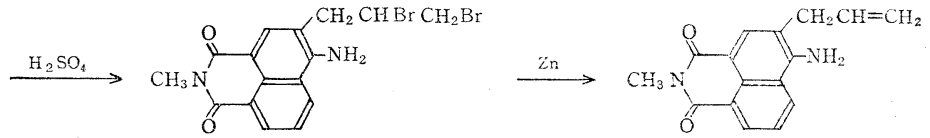

(13)
(14) 
に加水分解して相当する脱トシル化物 (8) を高収率で生 成する。しかし，(8) は不安定でジオキサン，水酢酸中 で加熱すると一部分解のおこることが pc で確認され た。したがってこの精製は室温でエタノールでよく洗浄 するにとどめた。

\section{III. 実験}

\section{4-トシルアミノナフタル酸-N-メチルイミド (1)}

前報6) にのべた方法によって合成した。mp 260〜 $261^{\circ} \mathrm{C}$ 。

2. 4-(N-アリル-N-トシルアミノ) ナフタル酸-Nメチルイミド (2) (1) $109 \mathrm{~g}(0.287$ モル) と炭酸 カリウム $59.4 \mathrm{~g}(0.430$ モル) を DMF $600 \mathrm{ml}$ 中で激 しくかきまぜながら $80 \sim 90^{\circ} \mathrm{C}$ に保ち，これに臭化アリ ル $51.6 \mathrm{~g}$ (0.430 モル) を 15 分間で滴下し，さらに 2.5 時間同温度でかくはんをつづけた。放泠後 $1.3 l$ の 水にあけ，析出物を口過し， $0.5 \%$ カセイソーダ水溶液 で洗浄して，混在する微量の未反応物を除き，ついで水， 希塩酸, 水で順次洗浄してほとんど純粋な目的物を得 た。収量 $119.7 \mathrm{~g}$ (収率 $99.3 \%$ ) , mp 141 $2^{\circ} \mathrm{C}$ 。工多 ノールから再結晶して得た純品は $\mathrm{mp} 141 \sim 2^{\circ} \mathrm{C}$ の白色 針状結晶。

分析值 $\mathrm{N}: 6.58 \%, \mathrm{C}: 65.67 \%, \mathrm{H}: 4.86 \%$

$\mathrm{C}_{23} \mathrm{H}_{20} \mathrm{~N}_{2} \mathrm{O}_{4} \mathrm{~S}$ としての計算值

$\mathrm{N}: 6.66 \%, \mathrm{C}: 65.70 \%, \mathrm{H}: 4.79 \%$

IR (KBr 錠剂法) : 1700, $1660(\mathrm{C}=\mathrm{O}), 1350,1160$ $\left(\mathrm{SO}_{2}\right), 935 \mathrm{~cm}^{-1}(\mathrm{C}-\mathrm{H}$, 末端オレフィン)。

$\mathrm{NMR}$ (溶媒 : $\mathrm{CDCl}_{3}$, 内部標準 : TMS) : 1.32 3.05 $\tau$ (9H, 芳香核プロトン), ca $4.4 \tau$ (m., $1 \mathbf{H}, \mathrm{CH}_{2} \mathrm{CH}=$ $\mathrm{CH}_{2}$ )，4.95 および $5.15 \tau$ (それぞれ微細構造の d., $2 \mathrm{H}, \mathrm{CH}=\mathrm{CH}_{2}$ ), $5.70 \tau$ (b.d., $2 \mathrm{H}, \mathrm{N}-\mathrm{CH}_{2}-\mathrm{CH}=$ ), $6.47 \tau$ (s., $3 \mathrm{H}, \mathrm{CH}_{3}-\mathrm{N}$ ), $7.55 \tau$ (s., $3 \mathrm{H}, \mathrm{CH}_{3}-\mathrm{C}_{6} \mathrm{H}_{4}-$ )。

\section{3-アリルー4ートシルアミノサフフタル酸 $-\mathrm{N}-$ メチル}

\section{イミド(3)への転位}

i. 無溶媒での転位 (2) $2.00 \mathrm{~g}$ を試験管にとり, 2 3 mmHg に減压したのら, あらかじめ $230^{\circ} \mathrm{C}$ に加熱 した油浴に $12 / 3$ 時閒浸せきした。放冷後, 内容物を DMF $10 \mathrm{~m} l$ で洗い出し, $1 \%$ カセイソーダ $100 \mathrm{~m} l$ にあ けて沈でんさせた。これをロ過してアルカリ不溶分を除 き, 不溶分はクロロホルム $25 \mathrm{ml}$ に溶解し, $0.5 \%$ カ七 イソーダ $25 \mathrm{ml}$ で 2 回抽出した。アルカリ溶液字あわ せ，塩酸酸性にすると白色結晶 $1.49 \mathrm{~g}, \mathrm{mp} 217.5 \sim 9^{\circ} \mathrm{C}$ が得られた。収率 $74.5 \%$ 。酢酸から再結晶して得た純 品は $\mathrm{mp} 223 \sim 3.5^{\circ} \mathrm{C}$ の白色針状結晶。

分析值 $\mathrm{N}: 6.61 \%, \mathrm{C}: 65.64 \%, \mathrm{H}: 4.87 \%$
$\mathrm{C}_{23} \mathrm{H}_{20} \mathrm{~N}_{2} \mathrm{O}_{4} \mathrm{~S}$ としての計算値

$\mathrm{N}: 6.66 \%, \mathrm{C}: 65.70 \%, \mathrm{H}: 4.79 \%$

IR (KBr 錠剤法) : $3275(\mathrm{NH}), 1700,1660(\mathrm{C}=\mathrm{O})$, 1350, $1165\left(\mathrm{SO}_{2}\right), 920 \mathrm{~cm}^{-1}(\mathrm{C}-\mathrm{H}$ ，末端オレフィン)。

NMR (溶媒: DMSO- $\mathrm{d}_{6}$, 内部標準 : TMS) : 1.65 $2.80 \tau\left(8 \mathrm{H}\right.$, 芳香核プロトン), ca $4.3 \tau$ (m., $1 \mathbf{H}, \mathrm{CH}_{2}$ $\mathrm{CH}=\mathrm{CH}_{2}$ ), ca $4.9 \tau$ (微細構造のb.d., $2 \mathbf{H},-\mathrm{CH}=\mathrm{CH}_{2}$ ), ca $6.6 \tau$ (solv. imp. と重なる。 $\mathrm{CH}_{2} \mathrm{CH}=\mathrm{CH}_{2}$ ), $6.68 \tau$ (s., $3 \mathbf{H}, \mathrm{CH}_{3}-\mathrm{N}$ ), $7.64 \tau$ (s., $3 \mathbf{H}, \mathrm{CH}_{3}-\mathrm{C}_{6} \mathrm{H}_{4}-$ )。

一方, クロロホルム溶液は水洗, 乾燥 (硫酸マグネシ ウム）後, 減压下に蒸発乾固し, 未反応原料 $0.51 \mathrm{~g}, \mathrm{mp}$ 130.5〜 $7^{\circ} \mathrm{C}$ を回収した。回収率 $25.5 \%$ 。

さらに 1) 常圧下, 2) $12 \sim 13 \mathrm{mmHg}, 3) 2 \sim 3 \mathrm{mmHg}$ 減压の 3 条件下で (2) $2.00 \mathrm{~g}$ 学 $213.1 \pm 0.2^{\circ} \mathrm{C}$ 亿加熱 反応し，上記と同様に処理した結果を表 1a〜e (II.1.) に示した。

ii. $\mathbf{N}, \mathbf{N}-$ ジエチルアニリン中での転立 (2) $2.00 \mathrm{~g}$ を試験管中ジェチルアニリン $5 \mathrm{ml}$ に溶解し, $213.0 \pm$ $0.2^{\circ} \mathrm{C}$ に保った油浴中に浸せき,一定時間ごとにとり出 し，反応混合物をそれぞれ $10 \%$ 塩酸 $100 \mathrm{ml}$ にあけて 結晶化し，この結晶をさらに塩酸で洗浄後，1\% カセイ ソーダで抽出してi．と同樣にアルカリ可溶分と不溶分 とに分け衣 2 (II.1.) の結果孛得た。

4. 3-プロペニル-4-トシルアミノナフタル酸-N-メ

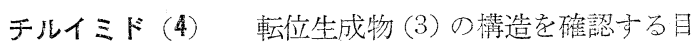
的でつぎのようにして (3) を合成しようと試みたが結果 的には (3) は得られず,（4) が得られた。

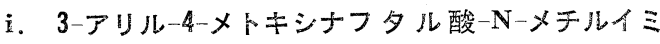
ドう（5）からの合成 ベンゼンとの其沸によって脱水 した DMSO $30 \mathrm{~m} l$ にp-トルエンスルホン酸アミド $3.68 \mathrm{~g}(0.021$ モル) 女溶解し, さらにナトリウムアミ ト $0.84 \mathrm{~g}(0.021$ モル $)$ を加えて中和したのち，3-アリ ルー4ーメトキシ体 $3.02 \mathrm{~g}$ (0.011 モル) を加えて $80^{\circ} \mathrm{C}$ で 5.5 時間かくはんした。反応混合物定 $300 \mathrm{ml}$ の $1 \%$ 力 さイソーダ水溶液に亦け析出物をろ別したのち, ジホキ サンから再結晶して $\mathrm{mp} 169 \sim 70^{\circ} \mathrm{C}$ の黄色針状結晶 30 $\mathrm{mg}$ 索得た。このものは混融試験执よび IR スペクトル からアリル基の 2 重結合が 1 位へ転位した3ープロペニ ルー4ーメトキシナフタル酸-N-ハチルイミド5) (6) (mp 171.5 2 $2^{\circ} \mathrm{C)}$ ) 西ることを確認した。

また, アルカリ溶液は塩酸酸性にして $\mathrm{mp} 211 \sim 39^{\circ} \mathrm{C}$ の黄色粉末 $2.90 \mathrm{~g}$ を得た。ジオキサンから再結晶（活 性炭処理）して得られた粉末 $0.91 \mathrm{~g}$ は mp 225.5 34 ${ }^{\circ} \mathrm{C}$ を示し，かなり不純なもので精㹈困難であったのでこれ 以上追求しなかった。しかしこの口液妾放置するとさら 


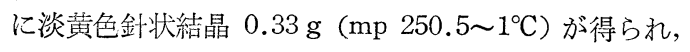
このものは IR スペクトルに trans-オレフィンの C-H (965 $\left.\mathrm{cm}^{-1}\right)$ が観察されたことおよび NMR から (4) で あると推測された。そこでつぎに述べる方法で (4)を合 成し，それとの混融試験，IR からこの推測に䛊りない ことを確認した。

ii. 3-アリル-4-トシルアミノナフタ ル酸-N-メチル イミド(3) からの合成 (3) $1.50 \mathrm{~g}$ (0.036モル) を DMSO $20 \mathrm{~m} l$ に溶解し, かくはん下 $60^{\circ} \mathrm{C}$ に保った。 これに，金属ナトリウム $0.17 \mathrm{~g}$ (0.072 グラム原子)を メタノール $10 \mathrm{ml}$ に溶解した液を一度に加え 2 時間か くはんをつつけた。放冷後内容物を $150 \mathrm{ml}$ の水にあ け，塩酸酸性にして $\mathrm{mp} 242 \sim 3.5^{\circ} \mathrm{C}(\mathrm{d})$ の結晶 $1.46 \mathrm{~g}$ (収率 97\%) を得た。これをジオキサンおよび DMF から各 2 回再結晶し, mp 256 6.5 ${ }^{\circ} \mathrm{C}$ (d) の淡黄色針 状結晶を得た。

分析值 N: $6.70 \%, \mathrm{C}: 65.55 \%, \mathrm{H}: 4.87 \%$ $\mathrm{C}_{23} \mathrm{H}_{20} \mathrm{~N}_{2} \mathrm{O}_{4} \mathrm{~S}$ としての計算值

$\mathrm{N}: 6.66 \%, \mathrm{C}: 65.70 \%, \mathrm{H}: 4.79 \%$

$\operatorname{IR}(\mathrm{KBr}$ 錠剂法): $3275(\mathrm{NH}), 1700,1660(\mathrm{C}=\mathrm{O})$, $1345,1162\left(\mathrm{SO}_{2}\right), 965 \mathrm{~cm}^{-1}(\mathrm{C}-\mathrm{H}$, trans-オレフィン)。

NMR (溶媒: DMSO- $\mathrm{d}_{6}$, 内 部標準: TMS) $1.80 \sim$ $2.68 \tau(8 \mathbf{H}$, 芳香核プロトン), ca $3.8 \tau(\mathrm{m} ., 2 \mathbf{H}, \mathbf{C H}=$ $\mathrm{CH}-\mathrm{CH}_{3}$ ), $6.68 \tau$ (s., $3 \mathbf{H}, \mathrm{CH}_{3}-\mathrm{N}$ ), $7.64 \tau$ (s., $3 \mathbf{H}$, $\mathrm{CH}_{3}-\mathrm{C}_{6} \mathrm{H}_{5}$ ), $8.39 \tau$ (b.d., $3 \mathbf{H}, \mathrm{CH}_{3}-\mathrm{CH}=\mathrm{CH}$ )

iii. 3-プロペニル-4-メトキシナフタル酸-N-メチル イミド5 (6) からの合成 (6) $1.81 \mathrm{~g}$ (0.0065 モル), pートルエンスルホン酸アミド $2.20 \mathrm{~g}$ (0.013 モル), ナ トリウムアミド $0.50 \mathrm{~g}$ (0.013 モル) および DMSO 15 $\mathrm{ml}$ を i. と同様に $85^{\circ} \mathrm{C}$ で 5 時間処理した。放冷後, $1 \%$ カセイソーダ水溶液 $160 \mathrm{~m} l$ にあけ, 不溶物 $0.28 \mathrm{~g}$,

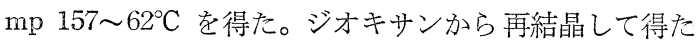
$\mathrm{mp} 169 \sim 70^{\circ} \mathrm{C}$ の淡黄色針状結晶は混融試験および IR から回収原料であることを確認した。回収率 $15.5 \%$ 。 カイセソーダ溶液は活性炭処理後, 塩酸酸性とし mp $226 \sim 34^{\circ} \mathrm{C}$ の結晶 $1.50 \mathrm{~g}$ を得た。ジオキサン $50 \mathrm{ml}$ か ら再結晶して $0.27 \mathrm{~g}$ の黄色粉末を得たが，このものは $\operatorname{mp} 229.5 \sim 32.5^{\circ} \mathrm{C}$ を示し, その IR から原料の加水分 解生成物，3-プロペニルー4-ヒドロキシナフタル酸 $-\mathrm{N}-$ メチルイミド5)であることを確認した。15.7\%。また， また, 再結晶母液は一たん蒸発乾固したのち, 改的て DMF から再結晶し, $\mathrm{mp} 250 \sim 50.5^{\circ} \mathrm{C}$ (d) の黄色針状 結晶 $0.72 \mathrm{~g}$ を得, 混融試験と IR から (4) であること を確認した。収率 $27 \%$ 。

5. 5-メチル-9-ブロムメチル-5, 6, 8, 9-テトラヒドロ

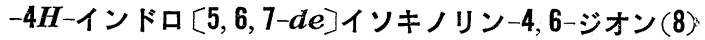
i. 10-トシル-(8) (7)
(3) $3.46 \mathrm{~g}(0.0082$ モル)

を DMF $25 \mathrm{~m} l$ に溶解, さらに炭酸カリウム $1.70 \mathrm{~g}$ を けん濁させ，これに臭素 $1.9 \mathrm{~g}$ (1.45 倍モル)-DMF $5 \mathrm{~m} l$ の溶液を室温で加え 2 時間かくはんした。析出物を口 別, $1 \%$ カセイソーダついで水で洗浄した。 $3.29 \mathrm{~g}, \mathrm{mp}$ $206.5 \sim 8^{\circ} \mathrm{C}(\mathrm{d})$, 収率 $80 \%$ 。水酢酸ついで DMF から各 2 回再結晶し $m p 211 \sim 212^{\circ} \mathrm{C}$ の淡黄色針状結晶を得た。 分析值 $\mathrm{N}: 5.43 \%, \mathrm{Br}: 16.15 \%$

$\mathrm{C}_{23} \mathrm{H}_{19} \mathrm{BrN}_{2} \mathrm{O}_{4} \mathrm{~S}$ としての計算值

$\mathrm{N}: 5.61 \%, \mathrm{Br}: 16.03 \%$

IR ( $\mathrm{KBr}$ 錠剤法) : $1705,1660(\mathrm{C}=\mathrm{O}), 1360,1175 \mathrm{~cm}^{-1}$ $\left(\mathrm{SO}_{2}\right)$

ii. （7）の硫酸加水分解による（8）の生成（7） $0.30 \mathrm{~g}$ を $83 \%$ 硫酸 $3 \mathrm{~m} l$ に溶解し $50 \sim 55^{\circ} \mathrm{C}$ に 25 分 間保った。反応混合物を氷水 $30 \mathrm{~m} l$ に市け, 生じた沈 でんを水および希アンモニア水で洗浄し, 乾燥した。 $0.18 \mathrm{~g}, 190^{\circ} \mathrm{C}$ 付近から徐々に着色分解, 粗収率 $87 \%$ 。 このものはジオキサンや酢酸中で加熱すると一部分解し (pc で確認)，再結晶することができなかったので室温 下エタノールでよく洗浄するのみで元素分析を行なっ た。

分析值 $\mathrm{N}: 8.13 \%, \mathrm{Br}: 23.27 \%$

$\mathrm{C}_{16} \mathrm{H}_{13} \mathrm{BrN}_{2} \mathrm{O}_{2}$ としての計算值

$\mathrm{N}: 8.12 \%, \mathrm{Br}: 23.15 \%$

IR : $3300(\mathrm{NH}), 1680,1640 \mathrm{~cm}^{-1}(\mathrm{C}=\mathrm{O})$ 。

6. 4-(N-アリル-N-トシルアミノ) ナフタル酸 $-\mathbf{N}-$ メチルイミド (2) の硫酸加水分解 $\quad$ (2) $5.00 \mathrm{~g}$ を $83 \%$ 硫酸 $25 \mathrm{ml}$ とともに振りまぜながら $60^{\circ} \mathrm{C}$ に 2 時間保 った。反応混合物ははじめけん濁状態であったが，しだ いに溶解し赤色を呈した。放冷後約 $500 \mathrm{~m} l$ の水水にあ け，カセイカリでアルカリ性としたのち，100 ml のク ロロホルムで各 3 回抽出した。クロロホルム層は水洗後 硫酸マゲネシウムで乾燥, 減圧下に蒸発乾固した。黄色 粉末 $2.30 \mathrm{~g}$ 。これを中性アルミナ (Woelm 社製)-アセ トン系でクロマト分離し, $\mathrm{mp} 169.5 \sim 74.5^{\circ} \mathrm{C}$ と $\mathrm{mp}$ $161 \sim 7^{\circ} \mathrm{C}$ の黄色粉末をそれぞれ $1.57 \mathrm{~g}, 0.45 \mathrm{~g}$, また, $\mathrm{mp} 271.5 \sim 2^{\circ} \mathrm{C}$ (d) のオレンジ色針状結晶 $0.12 \mathrm{~g}$ を得 た。前者はあわせてエタノールから再結晶し, mp 174.5 $\sim 5.5^{\circ} \mathrm{C}$ 黄色針状結晶を得, 元素分析值, IR および NMR から 4-アリルアミノナフタル酸-N-メチルイミド

（9）であることを確認した。粗収率 $64 \%$ 。 分析值 $\mathrm{C}: 72.09 \%, \mathrm{H}: 5.22 \%, \mathrm{~N}: 10.51 \%$ $\mathrm{C}_{16} \mathrm{H}_{14} \mathrm{~N}_{2} \mathrm{O}_{2}$ としての計算值 $\mathrm{C}: 72.17 \%, \mathrm{H}: 5.30 \%$. N : $10.52 \%$. 
IR (KBr 錠戍法) : $3400(\mathrm{NH}), 1690,1640(\mathrm{C}=\mathrm{O})$, $1630(\mathrm{C}=\mathrm{C}), 915 \mathrm{~cm}^{-1}(\mathrm{C}-\mathrm{H}$ 末端オレフィン)。

NMR (溶媒: DMSO- $\mathrm{d}_{6}$, 内部標準 : TMS) : 1.24 $3.39 \tau(5 \mathbf{H}$, 芳香核プロトン), $2.05 \tau$ (b.t., $1 \mathbf{H},-\mathrm{NH}-$ ), ca $3.93 \tau\left(\mathrm{m} ., 1 \mathbf{H}, \mathrm{CH}_{2}-\mathrm{CH}=\mathrm{CH}_{2}\right)$, ca $4.6,4.7,4.9 \tau$ (それぞれ微細構造の S., $2 \mathrm{H}, \mathrm{CH}_{2} \mathrm{CH}=\mathrm{CH}_{2}$ ), 5.98 г (微細構造の d., $2 \mathbf{H}, \mathrm{CH}_{2} \mathrm{CH}=\mathrm{CH}_{2}$ ), $6.63 \tau$ (s., $3 \mathbf{H}$, $\mathrm{CH}_{3}-\mathrm{N}$ )

また, mp 271.5 $2^{\circ} \mathrm{C}$ (d) のオレンジ色針状結晶は 水酢酸および DMF から各 1 回再結晶した。 $\mathrm{mp} 271$ $2^{\circ} \mathrm{C}$ (d)。このものは元素分析值, IR, NMR から 4-ア ミノ-3-(2-ヒドロキシプロピル) ナフタル酸-N-メチル イミド (10) であることを確認した。

分析值 C: $66.80 \%, \mathrm{H}: 5.52 \%, \mathrm{~N}: 9.58 \%$

$\mathrm{C}_{16} \mathrm{H}_{16} \mathrm{~N}_{2} \mathrm{O}_{3}$ としての計算值

$$
\mathrm{C}: 67.59 \%, \mathrm{H}: 5.67 \%, \mathrm{~N}: 9.86 \%
$$

IR ( $\mathrm{KBr}$ 錠剂法) : 3420, 3350, 3250(NH, OH), 1650 , $1630 \mathrm{~cm}^{-1}(\mathrm{C}=\mathrm{O})$

NMR (溶媒: DMSO- $\mathrm{d}_{6}$, 内部標準: TMS) : 1.38 $2.60 \tau(4 \mathrm{H}$, 芳香核プロトン。このうち $1.95 \tau(\mathrm{s} ., 1 \mathrm{H})$ に2 位のプロトン), $6.68 \tau$ (s., $3 \mathbf{H}, \mathbf{C H}_{3}-\mathrm{N}$ ), $7.22 \tau$ (d., $2 \mathbf{H}, \mathrm{N}-\mathrm{CH}_{2}-\stackrel{\prime}{\mathrm{C}} \mathrm{H}-$ ), $8.82 \tau$ (d., $3 \mathbf{H},-\stackrel{\prime}{\mathrm{C}} \mathrm{H}-\mathrm{CH}_{3}$ )。

7. 3-アリル-4-N-トシルアミノナフタル酸-N-メチ ルイミド (3) の硫酸加水分解 （3） $4.0 \mathrm{~g}$ を $83 \%$ 硫 酸 $20 \mathrm{ml}$ に汀儿濁し，振りまぜながら $55 \sim 60^{\circ} \mathrm{C}$ に 35 分間保った。反忘混合物はしだいに溶解し，均一な赤色 溶液となった。放冷後 $180 \mathrm{ml}$ の水にあけ析出物を口別 水でよく洗浄した。このものの $\mathrm{pc}^{*}$ は数種の物質の混 合物であることを示しており，再結晶法あるいはアルミ ナカラムによる分離精製を種々試みたがいずれからも単 品を得ることはできなかった。しかし，前記の口液から 新たに結晶が析出し，これをロ別して $\mathrm{mp} 270^{\circ} \mathrm{C}(\mathrm{d})$ の 黄色粉末 $0.86 \mathrm{~g}$ を得た。このものは $\mathrm{pc}, \mathrm{IR}$, および混 融試験により前述の（10）と同一物であることを確認し た。収率 $34 \%$ 。

\section{3-アリル-4-アミノナフタル酸-N-メチルイミド} (14) の合成

i. 3-アリル-4-(N-アセチル-N-トシルアミノ) ナフ タル酸-N-メチルイミド (11) （3） $2.90 \mathrm{~g}$ (0.007 モル) をピリジン $10 \mathrm{~m} l$ に溶解し, これに無水酢酸 $3 \mathrm{~m} l$ を 加えて室温で 2 昼夜放置後析出した結晶を集めた。 $2.06 \mathrm{~g}, \mathrm{mp} 179 \sim 180.5^{\circ} \mathrm{C}$, 収率 $64 \%$ 。水䣷酸加再結 晶し, $\mathrm{mp} 180.5 \sim 2^{\circ} \mathrm{C}$ の白色針状結晶を得た。

pcは東洋口紙 No. $50(2 \times 40 \mathrm{~cm})$ を $\alpha$-プロムナフタリンのベンや゙ ン溶液 $(10 \%)$ で前処理したものを用い， $\alpha$-ブロナフタリン飽和 $80 \%$ 酶酸水溶液で展開した。
分析值 $\mathrm{C}: 64.56 \%, \mathrm{H}: 4.84 \%, \mathrm{~N}: 6.23 \%$ $\mathrm{C}_{25} \mathrm{H}_{22} \mathrm{~N}_{2} \mathrm{O}_{5} \mathrm{~S}$ としての計算值

$$
\mathrm{C}: 64.92 \%, \mathrm{H}: 4.80 \%, \mathrm{~N}: 6.06 \%
$$

IR $(\mathrm{KBr}$ 錠剤法) : 1710, $1660(\mathrm{C}=\mathrm{O}), 1350,1160$ $\left(\mathrm{SO}_{2}\right), 920 \mathrm{~cm}^{-1}(\mathrm{C}-\mathrm{H}$ ，末端オンフィン)。

ii. 3-(2, 3-ジブロムプロピル)-4-(N-アセチル-Nトシルアミノ) ナフタル酸 $-\mathrm{N}-メ$ チルイミド（12）氷 酢酸 $15 \mathrm{ml}$ に(11) $1.76 \mathrm{~g}$ をけん濁し， $50 \sim 60^{\circ} \mathrm{C}$ で激 しくかきまぜながら臭素約 $0.2 \mathrm{ml}$ を加え，1.5 時間反 応させた。放冷後, 口過して mp $159.5 \sim 162^{\circ} \mathrm{C}$ (d) の 淡黄色結晶 $2.15 \mathrm{~g}$ を得た。このものを氷酢酸で 1 回, $\mathrm{DMF}$-永酢酸で 3 回再結晶し, $\mathrm{mp} 203 \sim 3.5^{\circ} \mathrm{C}$ の白色板 状結晶を得た。

分析值 $\mathrm{N}: 4.57 \%, \mathrm{Br}: 24.10 \%$

$\mathrm{C}_{25} \mathrm{H}_{22} \mathrm{Br}_{2} \mathrm{~N}_{2} \mathrm{O}_{5} \mathrm{~S}$ としての計算值

$$
\mathrm{N}: 4.50 \% \text {, Br : } 25.68 \%
$$

IR ( $\mathrm{KBr}$ 錠剤法) : 1705, $1665(\mathrm{C}=\mathrm{O}), 1360,1170$ $\mathrm{cm}^{-1}\left(\mathrm{SO}_{2}\right)$

iii. 3-(2,3-ジブロムプロピル)-4-アミノナフタル 酸-N-メチルイミド（13）（12） $0.62 \mathrm{~g}$ を $83 \%$ 硫酸 $6 \mathrm{~m} l$ に溶解し，ときどきふりまぜながら $50 \sim 60^{\circ} \mathrm{C}$ に 4 時閐保った。放冷後, $60 \mathrm{ml}$ の水にあけ析出する沈でんを 口別した。黄色粉末 $0.37 \mathrm{~g}, \mathrm{mp} 189^{\circ} \mathrm{C}(\mathrm{d})$, 粗収率 $87 \%$ 。 水酶酸, および DMFーメタノールから各 1 回再結晶し $\mathrm{mp} 201.5^{\circ} \mathrm{C}$ (d) の黄色プリズム状結晶を得た。

分析值 $\mathrm{N}: 6.56 \%, \mathrm{Br}: 37.64 \%$

琵 $\mathrm{C}_{16} \mathrm{H}_{14} \mathrm{Br}_{2} \mathrm{~N}_{2} \mathrm{O}_{2}$ としての計算值

$$
\mathrm{N}: 6.58 \%, \mathrm{Br}: 37.51 \%
$$

IR $(\mathrm{KBr}$ 錠剂法) : 3480, 3375, $3270(\mathrm{NH}), 1680$, $1630(\mathrm{C}=\mathrm{O})$ 。

iv. 3-アリル-4-アミノナフタル酸-N-メチルイミド (14) (13) $0.22 \mathrm{~g}$ を亜鉛末 $0.20 \mathrm{~g}$ とともに氷酢酸 $15 \mathrm{~m} l$ 中で 1 時間募沸還流した。放冷後不溶物を除去, 口液を減圧下に蒸発乾固した。残さを DMF $1.5 \mathrm{~m} l$ に 溶解して少量の不溶物を除いたのち水 $20 \mathrm{~m} l$ 中に注ぎ析 出する沈でん物を集めた。 $0.13 \mathrm{~g}, \mathrm{mp} 178.5 \sim 181.5^{\circ} \mathrm{C}$, 収率 $94 \%$ 。エタノールおよび承酢酸一メタノールから各 一回再結晶し，オレンジ色の長針状結晶を得た。mp 185 $\sim 5.5^{\circ} \mathrm{C}$ 。

分析值 C: $72.15 \%, \mathrm{H}: 5.26 \%, \mathrm{~N}: 10.52 \%$ $\mathrm{C}_{16} \mathrm{H}_{14} \mathrm{~N}_{2} \mathrm{O}_{2}$ としての計算值

$$
\text { C : } 72.17 \%, \mathrm{H}: 5.30 \%, \mathrm{~N}: 10.52 \%
$$

IR (KBr 錠剂法) : 3480, 3380, $3280(\mathrm{NH}), 1680$, $1630(\mathrm{C}=\mathrm{O}), 915 \mathrm{~cm}^{-1}(\mathrm{C}-\mathrm{H}$ ，末端オレフィン)。

NMR (溶媒 : DMSO- $\mathrm{d}_{6}$, 内部標準: TMS) : 1.21 
$2.52 \tau(4 \mathbf{H}$, 芳香核プロトン。このうち $1.91 \tau(\mathrm{s} ., 1 \mathbf{H})$ に2 位のプロトン), $2.97 \tau$ (b.s., $2 \mathbf{H}, \mathrm{NH}_{2}$ ), ca 3.9 $\left(\mathrm{m} ., 1 \mathrm{H}, \mathrm{CH}_{2} \mathrm{CH}=\mathrm{CH}_{2}\right), 4.68,4.75,4.96 \tau$ （それ资 れ微細構造の s., $2 \mathbf{H},-\mathrm{CH}_{2} \mathrm{CH}=\mathrm{CH}_{2}$ ) , 6.49 (b.d., $2 \mathbf{H}$, $\mathrm{CH}_{2} \mathrm{CH}=\mathrm{CH}_{2}$ ), $6.62 \tau$ (s., $3 \mathbf{H}, \mathrm{CH}_{3}-\mathrm{N}$ )。

本研究の実験の一部は古川安, 田中俊太郎雨君に上っ て行われた。元素分析, NMR 測定は岡部澄子, 吉田瑞 子両氏方担当され, また, 日本化薬(株), 三井東圧

(株), 三菱製紙 (株)，(株）リコーのご好意によると ころも多い。記して感謝の意を表する。

(本報告の一部は昭和 46 年度日本化学会東北地方大 会で講演発表した。講演要旨集 p. 37)

$$
\text { 文献 }
$$

1a) F.B. Dains, R.Q. Brewster, J.S. Blair, W.C.
Thompson, J. Amer. Chem. Soc. 442638 (1922)

b) F.L. Carnahan, C.D. Hurd, ibid. 524586 (1930)

2) S. Marcinkiewicz, J. Green, P. Mamalis, Tetrahedron 14208 (1961)

3) K.C. Brannock, R.D. Burpitt, J. Org. Chem. 263576 (1961); G. Opitz, Ann. 650122 (1961); J. Ficini, C. Barbara, Tetrahedron Lett. 1966 6425; R.K. Hill, N.W. Gilmann, ibid. 1967 1421; R.K. Hill, G.R. Newkome, ibid. 1968 5059

4) Y. Makisumi, Tetrahedron Lett. 19666413 Y. Makisumi, T. Sasatani, ibid. 1969543

5）稲田, 芝崎, 古川, 岡崎, 有合化 30549 (1972)

6) 稻田, 城崎, 岡崎, 有合化 30643 (1972)

\section{「有機合成化学協会誌」合本ファイル}

「有機合成化学協会誌」合本ファイル1部に1力年分 (12冊) がとじられるようになっています。 合本ファイル1部300 円（送料実費下表参照）の上前金にてお丮込み下さい。

小包料金表

(単位円)

\begin{tabular}{|c|c|c|c|c|c|}
\hline 地 帯 別 & 地 帯 内 都 道 府 県 名 & $\begin{array}{l}1 \sim 3 \text { 部 } \\
1 \mathrm{Kg} \text { 品 }\end{array}$ & $\begin{array}{l}4 \sim 7 \text { 部 } \\
2 \mathrm{Kg} \text { で }\end{array}$ & $\begin{array}{l}8 \text { 〜15部 } \\
4 \mathrm{Kg} \text { で }\end{array}$ & $\begin{array}{l}16 \sim 24 \text { 部 } \\
6 \mathrm{Kg} \text { 萡 }\end{array}$ \\
\hline \multirow[b]{2}{*}{ 第1地带 } & 東京都23区内 & 150 & 180 & 240 & 300 \\
\hline & $\begin{array}{l}\text { 東京都下, 山形, 宮城, 福島, 栃木, 茨城, 群馬, } \\
\text { 埼玉, 千葉, 神奈川, 新潟, 長野, 山梨, 静岡, } \\
\text { 富山, 石川, 岐阜, 愛知, 滋賀, 三重 }\end{array}$ & 200 & 250 & 350 & 450 \\
\hline 第 2 地带 & $\begin{array}{l}\text { 青森, 岩手, 秋田, 福井, 京都, 奈良, 兵庫, 大阪, } \\
\text { 和歌山, 鳥取, 島根, 岡山, 広島, 四国 } 4 \text { 県 }\end{array}$ & 300 & 350 & 450 & 550 \\
\hline 第 3 地带 & 山口, 北海道, 九州 7 県 & 400 & 450 & 550 & 650 \\
\hline
\end{tabular}

昰 113 東京都文京区本郷 2-39-7 越惣ビル 有機合成化学協会 合本用ファイル係 